\title{
Functional Studies of Tyrosine 108 Residue in the Active Site of Human Glutathione $S$-Transferase P1-1
}

\author{
Hee-Joong Park, Jong-Uk Koh, So-Youn Ahn, and Kwang-Hoon Kong* \\ Department of Chemistry, College of Sciences, Chung-Ang University, Seoul 156-756, Korea \\ *E-mail: khkong@cau.ac.kr \\ Received January 10, 2005
}

\begin{abstract}
To gain further insight on the relationship between structure and functions of glutathione $S$-transferase (GST), the three tyrosine 108 mutants, Y108A, Y108F, and Y108W, of human GST P1-1 were expressed in Escherichia coli and purified to electrophoretic homogeneity by affinity chromatography on immobilized GSH. The substitution of Tyr 108 with alanine resulted in significant decrease of the GSH-conjugation activity and the GSH peroxidase activity, but approximately $63 \%$ increase of steroid isomerase activity toward $\Delta^{5}-$ androstene 3,17-dione. On the other hand, the substitution of Tyr 108 with phenylalanine resulted in decreases of $k_{\mathrm{cat}}$ and $k_{\mathrm{cat}} / K_{\mathrm{m}}{ }^{\text {EPNP }}$ by 2 orders of magnitude, suggesting that Tyr 108 residue of hGSTP1-1 are considered to be important for the catalysis and the binding of the epoxide substrates. The substitution of Tyr 108 with tryptophan resulted in significant decreases of the specific activities toward EPNP, cumene hydroperoxide and $\Delta^{5}$-androstene 3,17-dione, but approximately 2 -fold increase on the enzyme-catalyzed addition of GSH to DCNB. We conclude from these results that Tyr 108 in hGST P1-1 plays very different roles depending upon the nature of the electrophilic substrates.
\end{abstract}

Key Words : Tyrosinase 108 residue, Enzymatic properties, Glutathione $S$-transferase, Substrate specificity

\section{Introduction}

Glutathione $S$-transferases (GSTs, EC 2.5.1.18) are a ubiquitous family of proteins whose primary functions are involved in the chemical and physical disposition of toxic substances. The chemical function of GSTs is to catalyze the formation of conjugates between reduced glutathione (GSH) and a wide variety of electrophilic compounds including alkyl- and aryl halides, epoxides, esters, and alkenes, the first step in mercaturic acid biosynthesis. ${ }^{1}$ Certain GSTs can also detoxify lipid and DNA hydroperoxide by their intrinsic peroxidase activity, ${ }^{2}$ while others catalyze the isomerization of certain steroids. ${ }^{3}$ Additionally they play an important role in the intracellular transport of numerous hydrophobic nonsubstrate ligands such as bile acids, billirubin, and a number of drugs. ${ }^{4}$ Although a number of investigations on GSTs have been performed, very little has been discovered concerning the relationship between their structures and functions.

GSTs are distributed in a wide range of organisms from mammals to Escherichia coli (E. coli). ${ }^{5}$ Mammalian cytosolic GSTs, which can exist as homo- or heterodimers, are grouped into at least five distinct classes, alpha, mu, pi, sigma, and theta according to based on studies of substrate specificity and primary structures. ${ }^{6,7}$ Human pi-class GST (hGST P1-1), a homodimeric protein of about $46 \mathrm{kDa}$ has attracted attention as reliable preneoplastic or neoplastic

Abbreviations: CP, cumene hydroperoxide; DCNB, 1,2-dichloro-4nitrobenzene; DNPG, $S$-(2,4-dinitrophenyl)glutathione; EPNP, 1,2epoxy-3-(p-nitrophenoxy)propane; Escherichia coli, E. coli; GSH, glutathione; G-site, glutathione-binding site; GST, glutathione $S$-transferase; hGST, human GST; H-site, electrophilic substrate-binding site. marker enzymes because a number of human tumors have been shown to express raised levels of the hGST P1-1 enzyme. ${ }^{8}$ Moreover, the hGST P1-1 has been implicated in the development of resistance of tumors towards various anti-cancer drugs in resistant tumor cells. ${ }^{9}$ Thus, the design of highly potent hGST P1-1 selective inhibitors may have increasing the therapeutic index of commonly used anticancer agents.

Recent crystallographic studies indicate that the polypeptide is organized into two domains, a GSH binding domain (domain $\mathrm{I}$ ) at the $\mathrm{N}$ terminus and a xenobiotic substrate binding domain (domain II) at the $\mathrm{C}$ terminus. ${ }^{10,11}$ The GSH-binding site (G-site) and the catalytic mechanism of these enzymes have been the targets of many investigations involving chemical modification, ${ }^{12-16}$ site-directed mutagenesis, ${ }^{17-23}$ and X-ray crystallographic analysis. ${ }^{24-26}$ Major roles of the active site in GST are the activation of the thiol group of reduced GSH for the nucleophilic reaction by deprotonation and the stabilization of the transition state for reactions with electrophilic substrates. The essential activesite residue has been revealed to be an evolutionarily conserved Tyr7 in hGST P1-1 by our previous studies. ${ }^{20,21}$ The extent of the information concerning the precise enzyme-GSH interactions responsible for the catalytic properties has been greatly increased by these studies. On the contrary, the electrophilic substrate-binding site (H-site) of GSTs has remained unclear for a long time. Subsequent crystallographic studies of all five GST classes show that the $\mathrm{H}$-site is quite different among them and very little is known about the key determinants of xenobiotic substrate specificity. ${ }^{10,11,24-27}$ Only a few amino acid residues have been identified as key determinants of the H-site : Tyr 115 in rat 
mu GST (isoenzymes 3-3 and 4-4), ${ }^{28,29}$ Met 208 in GST A1$1,{ }^{30}$ Ile 104 in GST P1-1, ${ }^{31}$ and Val 10, Arg 11, and Val 104 in the murine class pi GST. ${ }^{32}$

Previously, we reported the importance of Tyr 108 for the binding of the electrophilic substrate of hGST P1-1. ${ }^{33}$ As an extention of this study, we expressed the three tyrosine 108 mutants, Y108A, Y108F, and Y108W, of human GST P1-1 in $E$. coli and purified to electrophoretic homogeneity by affinity chromatography, and characterized with respect to their enzymatic properties, toward four selected substrates, i.e. 1,2-dichloro-4-nitrobenzene and 1,2-epoxy-3-( $p$-nitrophenoxy)propane for GSH-conjugation activity, cumene hydroperoxide for GSH peroxidase activity, and $\Delta^{5}$-androstene-3,17-dione for steroid isomerase activity. The results show that Tyr 108 plays very different roles depending upon the nature of the electrophilic cosubstrate. This study offers the information on the precise enzyme-substrate interactions responsible for the catalytic properties of hGST P1-1, and it will be of great value in designing new inhibitors that may prove useful in chemotherapy and new enzymes having different substrate specificity.

\section{Materials and Methods}

Materials. GSH and 1,2-dichloro-4-nitrobenzene were purchased from Kohjin Co. and Wako Pure Chem. Ind. (Osaka, Japan), respectively. Cumene hydroperoxide, 1,2epoxy-3-( $p$-nitrophenoxy)propane and $S$-methylGSH were obtained from Sigma (St. Louis, USA). $\Delta^{5}$-androstene-3,17dione was purchased from Steraloids Inc. (Wilton, N. H. USA). $S$-(2,4-Dinitrophenyl)glutathione was synthesized by the method of Schramm et al. ${ }^{34}$ Glutathione Sepharose was purchased from Pharmacia Biotech (Uppsala, Sweden). All other reagents used were of the highest grade commercially available.

Preparation of mutant enzymes. Wild-type hGST P1-1 was obtained by expression of a cloned $\mathrm{cDNA}^{35}$ in $E$. coli as described in the previous paper. ${ }^{19}$ Oligonucleotides 5'AAATACATCTCCCTCATCGCCACCAACTATGAG-3' (Tyr108Ala), 5'-AAATACATCTCCCTCATCTTCACCAACTATGAG-3' (Tyr108Phe), and 5'-AAATACATCTCCCTCATCT GGACCAACTATGAG-3' (Tyr108Trp) were synthesized for site-directed mutagenesis experiments. Mutagenesis was performed according to the procedure of Kunkel $^{36}$ using a Mutant ${ }^{\mathrm{TM}}$-Super Express Km kit (Takara Shuzo Co.). Construction of single-stranded DNA template for mutagenesis, confirmation of mutation, construction of the expression plasmid, expression and purification of the mutant enzymes were performed as described in the previous paper. ${ }^{33}$ Unless otherwise indicated, all purification procedures were carried out either at $4{ }^{\circ} \mathrm{C}$ or on ice. The enzymes were stored at $-70{ }^{\circ} \mathrm{C}$ until use.

Determination of protein concentration. Protein concentration of the wild type enzyme was determined by measuring the absorbance at $280 \mathrm{~nm}$ as described by Parker ${ }^{37}$ and protein concentration of the mutant was determined by using protein assay reagent (Bio-Rad Lab.) and the wild-type enzyme as a standard protein.

Enzyme activity and kinetic studies. The specific activities were determined by measuring the initial rates of the enzyme-catalysed conjugation of GSH with 1,2-dichloro4-nitrobenzene (DCNB) or 1,2-epoxy-3-(p-nitrophenoxy)propane (EPNP) as described by Habig and Jakoby. ${ }^{38}$ Assays were performed in a HITACHI U-2000 double-beam spectrophotometer (Hitachi Co., Tokyo, Japan) at $30{ }^{\circ} \mathrm{C}$ using cuvettes of $1 \mathrm{~cm}$ pathlength. Initial rates were measured for $5 \mathrm{~min}$, commencing $10 \mathrm{sec}$ after initial mixing. The reaction was initiated by $20 \mu \mathrm{L}$ of $50 \mathrm{mM}$ DCNB or EPNP to $860 \mu \mathrm{L}$ of $100 \mathrm{mM}$ potassium phosphate (pH 7.5) containing, in order of addition, $100 \mu \mathrm{L}$ of $50 \mathrm{mM}$ GSH and $20 \mu \mathrm{L}$ of the enzyme. Nonenzymatic reaction rates served as controls, and were subtracted from enzymatic rates. DCNB and EPNP were dissolved in ethanol. The concentration of ethanol in the reaction mixture $(1 \mathrm{~mL})$ was constant at $2 \%$ (v/v). GSH was dissolved in $\mathrm{H}_{2} \mathrm{O}$ immediately before use and kept in an ice-bath to prevent oxidation. The enzymes were diluted in $20 \mathrm{mM}$ potassium phosphate buffer ( $\mathrm{pH} 7.0$ ) containing $3 \mathrm{mM}$ EDTA, $3 \mathrm{mM}$ 2-mercaptoethanol, and $20 \%(\mathrm{v} / \mathrm{v})$ glycerol to a concentration that the enzymatic reaction rate was linear with time for up to $60 \mathrm{sec}$ after initiation, and up to a $\Delta \mathrm{A} / \mathrm{min}$ of 0.15 . All assays were done in the presence of $0.4 \%(\mathrm{v} / \mathrm{v})$ glycerol. Conditions were: (a) $1 \mathrm{mM}$ DCNB, $5 \mathrm{mM}$ GSH, $345 \mathrm{~nm}\left(\Delta \varepsilon=8.5 \mathrm{mM}^{-1} \mathrm{~cm}^{-1}\right)$ and (b) $0.5 \mathrm{mM}$ EPNP, $5 \mathrm{mM}$ GSH, $360 \mathrm{~nm}(\Delta \varepsilon=0.5$ $\left.\mathrm{mM}^{-1} \mathrm{~cm}^{-1}\right)$. A unit of activity is defined as the amount of enzyme catalyzing the formation of $1 \mu$ mole of product per min under the conditions of the specific assay. Specific activity is defined as the units of enzyme activity per mg of protein. Steroid isomerase activity was monitored by the catalyzed isomerization of $\Delta^{5}$-androstene-3,17-dione $(0.1$ $\mathrm{mM}$ ) to $\Delta^{4}$-androstene-3,17-dione, and was determined spectrophotometrically from the change in absorbance at $248 \mathrm{~nm}\left(\Delta \varepsilon=16.3 \mathrm{mM}^{-1} \mathrm{~cm}^{-1}\right)$ in $100 \mathrm{mM}$ potassium phosphate buffer, $\mathrm{pH} 6.5$, at $30^{\circ} \mathrm{C}$ in the presence of $3 \mathrm{mM}$ GSH. GSH-dependent peroxidase activity was assayed in the presence of $5 \mathrm{mM}$ GSH with $1.5 \mathrm{mM}$ cumene hydroperoxide $\left(\Delta \varepsilon=6.6 \mathrm{mM}^{-1} \mathrm{~cm}^{-1}\right)$ as substrate at $30^{\circ} \mathrm{C}$ as described. ${ }^{39}$ Kinetic studies with $\mathrm{GSH}$ and electrophilic substrates were carried out at $30^{\circ} \mathrm{C}$ as described by Chen $e t$ al. $^{17}$

Inhibition studies. The inhibitory effects on the activity of the enzyme were measured by preincubating the enzyme with $1 \mathrm{mM} \mathrm{GSH}$ and the inhibitor for $2 \mathrm{~min}$ and initiating the reaction by addition of $20 \mu \mathrm{L}$ of $50 \mathrm{mM}$ 1-chloro-2,4dinitrobenzene (final concentration, $1 \mathrm{mM}$ ). The concentration of inhibitor giving $50 \%$ inhibition $\left(I_{50}\right)$ was determined from plot of residual activity against inhibitor concentration.

Heat inactivation assays. The enzyme was incubated at each temperature for $10 \mathrm{~min}$ at a protein concentration of 0.1 $\mathrm{mg} / \mathrm{mL}$ in $20 \mathrm{mM}$ potassium phosphate buffer $(\mathrm{pH} 7.0)$ containing $10 \mathrm{mM}$ DTT and $10 \mathrm{mM}$ EDTA to prevent the oxidative inactivation, and then cooled in ice. The remaining activity was assayed in $100 \mathrm{mM}$ potassium phosphate buffer 
Table 1. Specific activity of the wild type and mutants for GSH-conjugation reaction towards 1,2-dichloro-4-nitrobenzene (DCNB) and 1,2epoxy-3-(p-nitrophenoxy) propane (EPNP)

\begin{tabular}{lccccc}
\hline & \multicolumn{2}{c}{ DCNB } & & \multicolumn{2}{c}{ EPNP } \\
\cline { 2 - 3 } \cline { 5 - 6 } Enzyme & $\begin{array}{c}\text { Specific activity } \\
\left(\times 10^{-2} \mu \mathrm{mol} / \mathrm{min} / \mathrm{mg}\right)\end{array}$ & $\begin{array}{c}\text { Relative } \\
\text { activity }(\%)\end{array}$ & & $\begin{array}{c}\text { Specific activity } \\
\left(\times 10^{-2} \mu \mathrm{mol} / \mathrm{min} / \mathrm{mg}\right)\end{array}$ & $\begin{array}{c}\text { Relative } \\
\text { activity }(\%)\end{array}$ \\
\hline Wild type & $11.8 \pm 1.1$ & 100 & & $36.0 \pm 3.8$ & 100 \\
Y108A & $6.8 \pm 0.2$ & 58 & & $13.3 \pm 1.0$ & 37 \\
Y108F & $11.8 \pm 0.1$ & 100 & & $2.5 \pm 0.1$ & 7 \\
Y108W & $25.4 \pm 1.7$ & 215 & & $12.4 \pm 1.5$ & 35 \\
\hline
\end{tabular}

Values are Means \pm S.D., generally based on $\mathrm{n} \geq 5$.

(pH 6.5) with $1 \mathrm{mM}$ GSH and $1 \mathrm{mM}$ 1-chloro-2,4dinitrobenzene at $30^{\circ} \mathrm{C}$. The enzyme was incubated in buffer $\mathrm{A}$ at various temperatures for $10 \mathrm{~min}$ and then cooled in ice.

\section{Results}

Purification of mutant enzymes. To investigate the effects of the steric and chemical properties of the side chain of tyrosine 108 in hGST P1-1, it was substituted with alanine, phenylalanine, and tryptophan by oligonucleotidedirected mutagenesis as described in the previous paper. ${ }^{33}$ The mutants of Tyr 108 residue expressed in Escherichia coli under the control of tac promoter were isolated and purified by affinity chromatography on immobilized GSH. The mutants Y108F and Y108W were isolated in a yield of approximately $2 \mathrm{mg}$ per liter of cultures as in the case of the wild type. On the other hand, in the cases of Y108A, the amount of the isolated enzyme was approximately $1 \mathrm{mg}$ per liter of culture because of its low affinity for GSHSepharose. The purified mutant enzymes were used for the studies of substrate specificity, inhibition and heat inactivation.

Substrate specificity. The specific activities of the mutant enzymes for GSH conjugation reaction are shown in Table 1. The substitution of Tyr 108 with alanine resulted in approximately $40-60 \%$ decrease of the specific activities toward DCNB and EPNP. The substitution of Tyr 108 with phenylalanine had negligible effect on the specific activity toward DCNB, but it resulted in approximately 90\% decrease of the specific activity toward EPNP. The substitution of Tyr 108 with tryptophan resulted in approximately $60 \%$ decrease of the specific activities toward EPNP, but it resulted in approximately $200 \%$ increase of the specific activity toward DCNB.

Organic hydroperoxides are substrates for GSTs. A study involving seven cytosolic homodimeric rat transferases demonstrated that linoleate hydroperoxide and arachidonate hydroperoxide in most cases gave activities comparable to the model substrate cumene hydroperoxide. ${ }^{40}$ The GSTcatalyzed reaction with cumene hydroperoxide represents the "nonselenium" glutathione peroxidase activity and is believed to occur in two steps involving an unstable glutathione sulfonic acid intermediate. Reduced GSH is regenerated from the produced glutathione disulfide (GSSG) by the action of glutathione reductase. ${ }^{41}$ The GSH peroxidase activities of the mutant enzymes are shown in Table 2. The substitutions of Tyr 108 with alanine and tryptophan resulted in approximately $80-90 \%$ decreases of the specific activity toward cumene hydroperoxide. On the other hand, the substitution of Tyr 108 with phenylalanine had negligible effect on the activity.

Several GSTs can catalyze the cis-trans isomerization of maleylacetone to fumarylactone and maleylacetoacetic acid to fumarylacetoacetic acid. An even smaller number of GST isozymes possess ketosteroid isomerase activity and catalyze the conversion of $\Delta^{5}$-3-ketosteroids to $\Delta^{4}$-3-ketosteroids. The steroid isomerase activities of the mutant enzymes are shown in Table 3. The substitution of Tyr 108 with tryptophan resulted in a decrease of the specific activity to approximately $36 \%$ of that of wild type. On the other hand, Y108A and Y108F resulted in approximately 50-60\% increase of specific activity toward $\Delta^{5}$-androstene 3,17 dione.

Kinetic studies. Table 4 summarizes the kinetic parameters of the mutant enzymes for GSH-DCNB conjugation

Table 2. Specific activity of the wild type and mutants for GSH peroxidase activity toward cumene hydroperoxide

\begin{tabular}{lcc}
\hline & \multicolumn{2}{c}{ Cumene hydroperoxide } \\
\cline { 2 - 3 } Enzymes & $\begin{array}{c}\text { Specific activity } \\
\left(\times 10^{-1} \mu \mathrm{mol} / \mathrm{min} / \mathrm{mg}\right)\end{array}$ & $\begin{array}{c}\text { Relative activity } \\
(\%)\end{array}$ \\
\hline Wild type & $37.2 \pm 3.3$ & 100 \\
Y108A & $0.9 \pm 0.1$ & 2 \\
Y108F & $28.8 \pm 0.7$ & 77 \\
Y108W & $6.1 \pm 0.5$ & 16 \\
\hline
\end{tabular}

Values are Means \pm S.D., generally based on $n \geq 5$.

Table 3. Specific activity of the wild type and mutants for steroid isomerase activity toward $\Delta^{5}$-androstene-3,17-dione

\begin{tabular}{lcc}
\hline \multirow{2}{*}{ Enzymes } & \multicolumn{2}{c}{$\Delta^{5}$-Androstene-3,17-dione } \\
\cline { 2 - 3 } & $\begin{array}{c}\text { Specific activity } \\
\left(\times 10^{-1} \mu \mathrm{mol} / \mathrm{min} / \mathrm{mg}\right)\end{array}$ & $\begin{array}{c}\text { Relative activity } \\
(\%)\end{array}$ \\
\hline Wild type & $7.8 \pm 0.1$ & 100 \\
Y108A & $12.7 \pm 0.2$ & 163 \\
Y108F & $11.7 \pm 0.4$ & 149 \\
Y108W & $2.8 \pm 0.1$ & 36
\end{tabular}

Values are Means \pm S.D., generally based on $n \geq 5$. 
Table 4. Enzymatic kinetic parameters for GSH-[1,2-Dichloro-4-nitrobenzene] conjugation

\begin{tabular}{|c|c|c|c|c|c|c|}
\hline \multirow[b]{2}{*}{ Enzyme } & \multicolumn{3}{|c|}{ GSH } & \multicolumn{3}{|c|}{ DCNB } \\
\hline & $\begin{array}{c}K_{\mathrm{m}} \\
(\mathrm{mM})\end{array}$ & $\begin{array}{c}k_{\text {cat }} \\
\left(\times 10^{-2} \mathrm{~s}^{-1}\right)\end{array}$ & $\begin{array}{c}k_{\text {cat }} / K_{\mathrm{m}} \\
\left(\times 10^{-2} \mathrm{mM}^{-1} \mathrm{~s}^{-1}\right)\end{array}$ & $\begin{array}{c}K_{\mathrm{m}} \\
(\mathrm{mM})\end{array}$ & $\begin{array}{c}k_{\mathrm{cat}} \\
\left(\times 10^{-2} \mathrm{~s}^{-1}\right)\end{array}$ & $\begin{array}{c}k_{\mathrm{cat}} / K_{\mathrm{m}} \\
\left(\times 10^{-2} \mathrm{mM}^{-1} \mathrm{~s}^{-1}\right)\end{array}$ \\
\hline Wild type & $0.29 \pm 0.08$ & $4.1 \pm 1.0$ & 14.1 & $0.65 \pm 0.03$ & $2.1 \pm 0.9$ & 3.2 \\
\hline Y108A & $0.40 \pm 0.01$ & $4.1 \pm 1.1$ & 10.3 & $0.84 \pm 0.03$ & $1.1 \pm 0.9$ & 1.3 \\
\hline Y108F & $0.08 \pm 0.01$ & $1.1 \pm 0.5$ & 13.8 & $0.45 \pm 0.08$ & $1.1 \pm 0.9$ & 2.4 \\
\hline Y108W & $0.09 \pm 0.01$ & $7.0 \pm 0.8$ & 77.8 & $0.27 \pm 0.05$ & $3.2 \pm 0.8$ & 11.9 \\
\hline
\end{tabular}

Values are means \pm SD, generally based on $n \geq 3$.

Table 5. Enzymatic kinetic parameters for GSH-[1,2-Epoxy-3-( $p$-nitrophenoxy)propane] conjugation

\begin{tabular}{|c|c|c|c|c|c|c|}
\hline \multirow[b]{2}{*}{ Enzyme } & \multicolumn{3}{|c|}{ GSH } & \multicolumn{3}{|c|}{ EPNP } \\
\hline & $\begin{array}{c}K_{\mathrm{m}} \\
(\mathrm{mM})\end{array}$ & $\begin{array}{c}k_{\mathrm{cat}} \\
\left(\times 10^{-2} \mathrm{~s}^{-1}\right)\end{array}$ & $\begin{array}{c}k_{\mathrm{cat}} / K_{\mathrm{m}} \\
\left(\times 10^{-2} \mathrm{mM}^{-1} \mathrm{~s}^{-1}\right)\end{array}$ & $\begin{array}{c}K_{\mathrm{m}} \\
(\mathrm{mM})\end{array}$ & $\begin{array}{c}k_{\mathrm{cat}} \\
\left(\times 10^{-2} \mathrm{~s}^{-1}\right)\end{array}$ & $\begin{array}{c}k_{\mathrm{cat}} / K_{\mathrm{m}} \\
\left(\times 10^{-2} \mathrm{mM}^{-1} \mathrm{~s}^{-1}\right)\end{array}$ \\
\hline Wild type & $0.40 \pm 0.02$ & $1.08 \pm 0.06$ & 2.70 & $0.25 \pm 0.09$ & $2.01 \pm 0.09$ & 8.04 \\
\hline Y108A & $0.40 \pm 0.04$ & $1.32 \pm 0.07$ & 3.30 & $1.30 \pm 0.02$ & $1.12 \pm 0.08$ & 0.86 \\
\hline Y108F & $0.46 \pm 0.04$ & $1.07 \pm 0.02$ & 2.33 & $1.84 \pm 0.03$ & $0.31 \pm 0.01$ & 0.17 \\
\hline Y108W & $0.48 \pm 0.04$ & $1.50 \pm 0.12$ & 3.12 & $0.13 \pm 0.07$ & $3.02 \pm 0.12$ & 23.23 \\
\hline
\end{tabular}

Values are means $\pm S D$, generally based on $n \geq 3$.

activity. The substitution of Tyr 108 with alanine resulted in a 1.4-fold increase of $K_{\mathrm{m}}{ }^{\mathrm{GSH}}$ and $K_{\mathrm{m}}{ }^{\mathrm{DCNB}}$, whereas the $K_{\mathrm{m}}{ }^{\mathrm{GSH}}$ value of the $\mathrm{Y} 108 \mathrm{~F}$ was a 3.6-fold lower than that of the wild type. The substitution of Tyr 108 with tryptophan resulted in approximately 2-3 fold decreases of $K_{\mathrm{m}}$ values, approximately 1.5-fold increases of $k_{\text {cat }}$ values and approximately 46 fold increases of $k_{\text {cat }} / K_{\mathrm{m}}$.

Table 5 summarizes the kinetic parameters of the mutant enzymes for GSH-EPNP conjugation activity. The substitution of Tyr 108 significantly affected $K_{\mathrm{m}}{ }^{\text {EPNP }}$, whereas scarcely affected $K_{\mathrm{m}}{ }^{\mathrm{GSH}}$. The substitution of Tyr 108 with phenylalanine resulted in a 7.4- fold increase of $K_{\mathrm{m}}{ }^{\text {EPNP }}$, a 6.5-fold decrease of $k_{\text {cat }}$ and a 47 -fold decrease of $k_{\text {cat }} / K_{\mathrm{m}}{ }^{\text {EPNP }}$.
On the other hand, the substitution of Tyr 108 with tryptophan resulted in a 1.9 -fold decrease of $K_{\mathrm{m}}{ }^{\mathrm{EPNP}}$, a 1.5 fold increase of $k_{\text {cat }}$ and a 3-fold increase of $k_{\text {cat }} / K_{\mathrm{m}}{ }^{\text {EPNP }}$.

Table 6 summarizes the kinetic parameters of the mutant enzymes for GSH peroxidase activity. The substitution of Tyr 108 with alanine resulted in a 10-fold increase of $K_{\mathrm{m}}{ }^{\mathrm{GSH}}$, whereas the $\mathrm{Y} 108 \mathrm{~F}$ and $\mathrm{Y} 108 \mathrm{~W}$ were similar to that of the wild type. On the other hand, the $K_{\mathrm{m}}{ }^{\mathrm{CP}}$ values of the mutant enzymes were approximately 3-27 fold larger than that of the wild type. Particularly, the substitution of Tyr 108 with alanine resulted in a 27 - fold increase of $K_{\mathrm{m}}{ }^{\mathrm{CP}}$, a 48 -fold decrease of $k_{\mathrm{cat}}$ and a 1280 -fold decrease of $k_{\mathrm{cat}} / K_{\mathrm{m}}{ }^{\mathrm{CP}}$.

Table 7 summarizes the kinetic parameters of the mutant

Table 6. Enzymatic kinetic parameters for GSH peroxidase activity toward cumene hydroperoxide

\begin{tabular}{|c|c|c|c|c|c|c|}
\hline \multirow[b]{2}{*}{ Enzyme } & \multicolumn{3}{|c|}{ GSH } & \multicolumn{3}{|c|}{ Cumene hydroperoxide } \\
\hline & $\begin{array}{c}K_{\mathrm{m}} \\
(\mathrm{mM})\end{array}$ & $\begin{array}{c}k_{\mathrm{cat}} \\
\left(\times 10^{-2} \mathrm{~s}^{-1}\right)\end{array}$ & $\begin{array}{c}k_{\mathrm{cat}} / K_{\mathrm{m}} \\
\left(\times 10^{-2} \mathrm{mM}^{-1} \mathrm{~s}^{-1}\right)\end{array}$ & $\begin{array}{c}K_{\mathrm{m}} \\
(\mathrm{mM})\end{array}$ & $\begin{array}{c}k_{\text {cat }} \\
\left(\times 10^{-2} \mathrm{~s}^{-1}\right)\end{array}$ & $\begin{array}{c}k_{\mathrm{cat}} / K_{\mathrm{m}} \\
\left(\times 10^{-2} \mathrm{mM}^{-1} \mathrm{~s}^{-1}\right)\end{array}$ \\
\hline Wild type & $0.17 \pm 0.08$ & $13.7 \pm 1.5$ & 80.6 & $0.30 \pm 0.02$ & $96.0 \pm 4.0$ & 320.0 \\
\hline Y108A & $1.76 \pm 0.01$ & $17.0 \pm 2.1$ & 9.7 & $8.00 \pm 0.01$ & $2.0 \pm 0.3$ & 0.3 \\
\hline Y108F & $0.16 \pm 0.01$ & $10.2 \pm 1.4$ & 63.8 & $2.11 \pm 0.08$ & $81.0 \pm 5.1$ & 38.4 \\
\hline Y108W & $0.20 \pm 0.11$ & $16.1 \pm 1.9$ & 80.5 & $0.90 \pm 0.01$ & $27.0 \pm 2.0$ & 30.0 \\
\hline
\end{tabular}

Values are means \pm SD, generally based on $n \geq 3$.

Table 7. Enzymatic kinetic parameters for steroid isomerase activity toward $\Delta^{5}$-androstene-3,17-dione

\begin{tabular}{|c|c|c|c|c|c|c|}
\hline \multirow[b]{2}{*}{ Enzyme } & \multicolumn{3}{|c|}{ GSH } & \multicolumn{3}{|c|}{$\Delta^{5}$-Androstene-3,17-dione } \\
\hline & $\begin{array}{c}K_{\mathrm{m}} \\
(\mathrm{mM})\end{array}$ & $\begin{array}{c}k_{\text {cat }} \\
\left(\times 10^{-2} \mathrm{~s}^{-1}\right)\end{array}$ & $\begin{array}{c}k_{\mathrm{cat}} / K_{\mathrm{m}} \\
\left(\times 10^{-2} \mathrm{M}^{-1} \mathrm{~s}^{-1}\right)\end{array}$ & $\begin{array}{c}K_{\mathrm{m}} \\
(\mathrm{mM})\end{array}$ & $\begin{array}{c}k_{\text {cat }} \\
\left(\times 10^{-2} \mathrm{~s}^{-1}\right)\end{array}$ & $\begin{array}{c}k_{\text {cat }} / K_{\mathrm{m}} \\
\left(\times 10^{-2} \mathrm{mM}^{-1} \mathrm{~s}^{-1}\right)\end{array}$ \\
\hline Wild type & $0.88 \pm 0.04$ & $2.4 \pm 0.8$ & 2.7 & $0.43 \pm 0.09$ & $15.0 \pm 1.0$ & 34.9 \\
\hline Y108A & $0.67 \pm 0.05$ & $18.0 \pm 1.4$ & 26.9 & $0.49 \pm 0.02$ & $11.2 \pm 1.4$ & 22.9 \\
\hline Y108F & $0.71 \pm 0.04$ & $11.0 \pm 1.1$ & 15.5 & $1.29 \pm 0.07$ & $8.6 \pm 0.6$ & 6.7 \\
\hline Y108W & $0.48 \pm 0.03$ & $4.1 \pm 0.3$ & 8.5 & $3.28 \pm 0.13$ & $20.5 \pm 0.3$ & 6.3 \\
\hline
\end{tabular}

Values are means $\pm S D$, generally based on $n \geq 3$. 


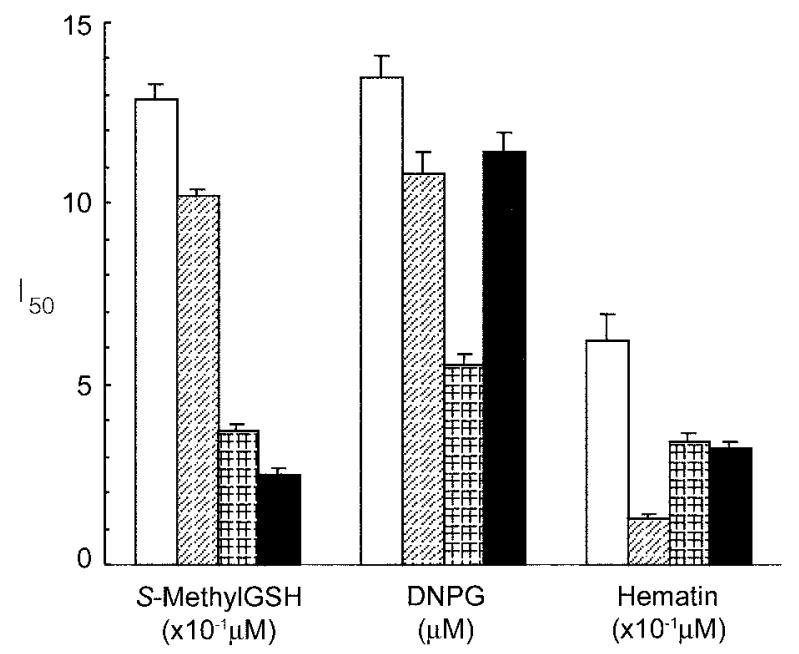

Figure 1. Effect of inhibitors on the GSH conjugation activity of the wild type and mutant enzymes. Wild type, $\square$; Y108A, $\square$; Y108F, 曲; Y108W, - . The inhibitors were (a) S-methylGSH $\left(\times 10^{-1} \mu \mathrm{M}\right)$, (b) $S$-(2,4-dinitrophenyl)GSH $(\mu \mathrm{M})$ and (c) hematin $\left(\times 10^{-1} \mu \mathrm{M}\right)$. Values are Means \pm S.D., generally based on $n \geq 5$.

enzymes for steroid isomerase activity. The substitution of Tyr 108 with tryptophan resulted in a 2-fold decrease of $K_{\mathrm{m}}^{\mathrm{GSH}}$, whereas $K_{\mathrm{m}}{ }^{\text {STEROID }}$ value resulted in a 7.6-fold increase. On the other hand, the $K_{\mathrm{m}}{ }^{\mathrm{GSH}}$ values of the Y108A and Y108F were similar to that of the wild type.

Inhibition studies. The inhibition parameters $\left(I_{50}\right)$ of various kinds of inhibitors, $S$-methylGSH, $S$-(2,4-dinitrophenyl)glutathione and hematin for GSH-CDNB conjugating activity were determined under the standard assay conditions (Figure 1). The substitutions of Tyr 108 with phenylalanine and tryptophan resulted in approximately 3fold decreases in the $I_{50}$ values of $S$-methylGSH that compete with GSH. On the other hand, the $I_{50}$ value of $S$ methylGSH for Y108A was similar to that of the wild type. The $I_{50}$ values of $S$-(2,4-dinitrophenyl)glutathione, a conjugation product of GSH with CDNB, for Y108A and Y108W were a little lower than that of the wild type, as shown in Figure 1. On the other hand, the $I_{50}$ value for $\mathrm{Y} 108 \mathrm{~F}$ was significantly lower than the wild-type value about 2-fold. The $I_{50}$ values of hematin, a nonsubstrate ligand, for mutant enzymes were significantly lower than that of the wild type about 2-3 fold.

Heat inactivation of the wild type and mutant enzymes. After the enzymes were incubated in $20 \mathrm{mM}$ potassium phosphate buffer ( $\mathrm{pH} 7.0$ ) at various temperatures for 10 min, the remaining activities were assayed in $100 \mathrm{mM}$ potassium phosphate buffer ( $\mathrm{pH} 6.5$ ) at $30^{\circ} \mathrm{C}$ (Figure 2). The wild type, Y108A and Y108F were fairly stable to such an incubation at temperature up to $50{ }^{\circ} \mathrm{C}$, but were inactivated irreversibly above $50^{\circ} \mathrm{C}$. Y $108 \mathrm{~W}$ mutant was unstable than the wild type. The midpoints of inactivation were $57^{\circ} \mathrm{C}$ for the wild type, whereas $53{ }^{\circ} \mathrm{C}$ for $\mathrm{Y} 108 \mathrm{~W}$ mutant.

\section{Discussion}

Human GST P1-1 (hGST P1-1) has been extensively

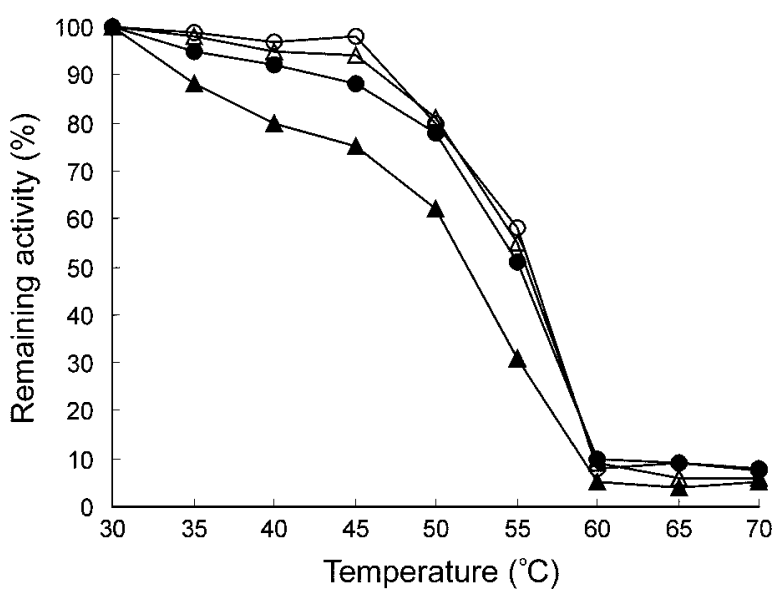

Figure 2. Thermostability of the wild type and mutant enzymes. Wild type, $\bigcirc$; Y108A, ๑ Y Y108F, $\triangle$; Y108W, $\wedge$.

studied because of the clinical interest in it as a marker during chemical carcinogenesis and its potential role in the mechanism of cellular multidrug resistance against a number of antineoplastic agents. ${ }^{42}$ Thus, studies on the relationship between structure and function of hGST P1-1 provide a rationale for the design of inhibitors and prodrugs to enhance therapeutic index. The hGST P1-1 subunit consists of the Nterminal 76 residues (domain I) and the C-terminal 127 residues (domain II) which are connected by a six residue linker. ${ }^{27}$ Most of the residues (Arg13, Lys44, Gln51, Gln64 and Asp98) necessary for binding of GSH occupied a site on domain I (G-site). On the other hand, little is known about the location of the binding site of electrophilic substrates $(\mathrm{H}-$ site). The chemical modification studies have suggested that Tyr residue in GST is located at or close to the substratebinding site of the enzyme. Barycki and Colman suggested that Tyr 115 in class mu GST 4-4 contributes to xenobiotic substrate binding by chemical modification study using 4(fluorosulfonyl)benzoic acid, a xenobiotic substrate analogue. ${ }^{43}$ Affinity labeling study using 4-(fluorosulfonyl)benzoic acid also provided another evidence that Tyr 106 of the pig lung class pi GST is located at or close to the substrate binding site of the enzyme. ${ }^{44}$ X-ray crystallographic studies have also suggested that Tyr 108 in hGST P1-1 is located at the substrate-binding site and it is in a structurally conserved position within the mu, pi and theta classes, and appears to be one of the few polar residues contributing to the H-site. ${ }^{27-32}$ In order to elucidate the precise enzyme-substrate interactions responsible for the catalytic properties of GST, the mutant enzymes of Tyr 108 residue in hGST P1-1 were expressed in E. coli, purified to electrophoretic homogeneity by affinity column chromatography and examined the enzymatic properties of the mutated enzymes. The substitutions of Tyr 108 with alanine, phenylalanine and tryptophan greatly affected the catalytic properties of hGST P1-1 toward a number of substrates, as discussed below.

The substitution of Tyr 108 with alanine significantly affected GSH-conjugation activity, GSH peroxidase activity 
and steroid isomerase activity. The substitution of Tyr 108 with alanine resulted in approximately 40-60\% decrease of the specific activities toward DCNB and EPNP and $98 \%$ decrease of the GSH peroxidase activity toward cumene hydroperoxide (Table 1 and 2). This substitution also resulted in large increases of $K_{\mathrm{m}}$ values toward electrophilic substrates (Table 5 and 6) and a significant decrease of $I_{50}$ value for hematin (Fig. 1). On the other hand, the substitution of Tyr 108 with alanine resulted in approximately $63 \%$ increase of steroid isomerase activity toward $\Delta^{5}$ androstene 3,17-dione (Table 3). This substitution also resulted in about 7-fold increase of the $k_{\text {cat }}$ value for GSH compared to that of the wild-type enzyme (Table 7). This higher catalytic efficiency was explained with the removal of the hydroxyl function of Tyr 108 limits the product release (rate-limiting).

The substitution of Tyr 108 with phenylalanine had a dramatic effect on the enzyme-catalyzed addition of GSH to EPNP, reducing $k_{\text {cat }}$ and $k_{\text {cat }} / K_{\mathrm{m}}{ }^{\text {EPNP }}$ by 2 orders of magnitude (Table 1 and 5). There were little differences in the activities of the Y108F mutant and the wild-type enzyme toward DCNB, cumene hydroperoxide and $\Delta^{5}$-androstene 3,17-dione (Table 1, 2 and 3). Thus, the severely impaired catalytic efficiency of the Y108F mutant was consistent with the removal of an interaction crucial for the chemical step of the reaction and not a deterious change in the conformation of the active site. Similar results about the effect of this residue on epoxide conjugation have been reported by Johnson et al. using site-directed mutagenesis and crystallographic analysis for isozyme 3-3 of rat GST. ${ }^{28} \mathrm{Ji}$ et al. also suggested the role of the hydroxyl group of Tyr 108 as an electrophilic participant in the addition of GSH to epoxides. ${ }^{45}$ From these results, Tyr 108 residue of hGSTP1-1 are considered to be important for the catalysis and the binding of the epoxide substrates.

The substitution of Tyr 108 with tryptophan resulted in 65$84 \%$ decreases of the specific activities toward EPNP, cumene hydroperoxide and $\Delta^{5}$-androstene 3,17-dione (Table 1, 2 and 3). On the other hand, the substitution of Tyr 108 with phenylalanine resulted in approximately 2-fold increase on the enzyme-catalyzed addition of GSH to DCNB. This substitution resulted in 2-3 fold decreases of $K_{\mathrm{m}}$ values on substrates and $I_{50}$ value on $S$-methylGSH, and 4-6 fold increase $k_{\text {cat }} / K_{\mathrm{m}}$ (Table 1, 4 and Fig. 1). Y108W mutant also was unstable against heat than the wild-type enzyme (Fig. 2). These results suggest that the substitution of Tyr 108 with tryptophan changes the conformation of the active site to increase the affinity for substrates. Tyr 108 of hGST P1-1, the equivalent to Tyr 115 in class mu, was positioned in close contact to the xenobiotic substrate and was a possible candidate for involvement in $\mathrm{H}$-site.

These rather striking differences in the response of the catalytic properties of the mutant enzymes are most likely to be correlated with structural differences between their active-sites, and the substitutions of Tyr 108 might affect the interaction between the thiol group and Tyr 7 through distorting the orientation of the GSH bound in the enzyme and/or the binding site of electrophilic substrates. We conclude from these results that Tyr 108 in hGST P1-1 can play different roles depending upon the nature of the electrophilic substrates.

Acknowledgment. This Research was supported by the Creative Initiative Research Program of Chung-Ang University in 2003.

\section{References}

1. Mannervik, B.; Danielson, U. H. CRC Crit. Rev. Biochem. 1988 , 23, 283.

2. Mayer, D. J.; Beale, D.; Tan, K. H.; Coles, B.; Ketterer, B. FEBS Lett. 1985, 184, 139.

3. Benson, A. M.; Talalay, P.; Keen, J. H.; Jakoby, W. B. Proc. Natl. Acad. Sci. USA 1977, 74, 158.

4. Litwack, G.; Ketterer, B.; Arias, I. M. Nature (London) 1971, 234, 466.

5. Fahey, R. C.; Sundquist, A. R. Adv. Enzymol. Rel. Areas Mol. Biol. 1991, 64, 1 .

6. Mannervik, B. Adv. Enzymol. Rel. Areas Mol. Biol. 1985, 57, 357.

7. Mannervik, B.; Awasthi, Y. C.; Board, P. G.; Hayes, J. D.; Ilio, C.; Ketterer, B.; Listowsky, I.; Morgenstern, R.; Muramatsu, M.; Pearson, W. R.; Pickett, C. B.; Sato, K.; Widersten, M.; Wolf, C. R. Biochem. J. 1992, 282, 305.

8. Tsuchida, S.; Sato, K. CRC Crit. Rev. Biochem. Mol. Biol. 1992, 27, 337.

9. Morgan, A. S.; Ciaccio, P. J.; Tew, K. D.; Kauvar, L. M. Cancer Chemother. Pharmacol. 1996, 37, 363.

10. Reinemer, P.; Dirr, H. W.; Ladenstein, R.; Schäffer, J.; Gallay, O.; Huber, R. EMBO J. 1991, 10, 1997.

11. Ji, X.; Zhang, P.; Armstrong, R. N.; Gilliland, G. L. Biochemistry 1992, 31, 10169.

12. Caccuri, A. M.; Petruzzelli, R.; Polizio, F.; Federici, G.; Desideri, A. Arch. Biochem. Biophys. 1992, 297, 119.

13. Desideri, A.; Caccuri, A. M.; Poligio, F.; Bastoni, R.; Federici, G. J. Biol. Chem. 1991, 266, 2063.

14. Lo Bello, M.; Petruzzelli, R.; De Stefano, E.; Tenedini, C.; Barra, D.; Federici, G. FEBS Lett. 1990, 263, 389.

15. Nishikawa, T.; Maeda, H.; Okamoto, K.; Oshida, T.; Mizoguchi, T.; Terada, T. Biochem. Biophys. Res. Commun. 1991, 174, 580.

16. Tamai, K.; Satoh, K.; Tsuchida, S.; Hatayama, I.; Maki, T.; Sata, K. Biochem. Biophys. Res. Commun. 1990, 167, 331.

17. Chen, W.-L.; Haieh, J.-C.; Hong, J.-L.; Tsai, S.-P.; Tam, M. F. Biochem. J. 1992, 286, 205.

18. Haieh, J.-C.; Huang, S.-C.; Chen, W.-L.; Lai, Y.-C.; Tam, M. F. Biochem. J. 1991, 278, 293.

19. Kong, K.-H.; Inoue, H.; Takahashi, K. Biochem. Biophys. Res. Commun. 1991, 181, 748.

20. Kong, K.-H.; Nishida, M.; Inoue, H.; Takahashi, K. Biochem. Biophys. Res. Commun. 1992, 182, 1122.

21. Kong, K.-H.; Takasu, K.; Inoue, H.; Takahashi, K. Biochem. Biophys. Res. Commun. 1992, 184, 194.

22. Kong, K.-H.; Inoue, H.; Takahashi, K. Protein Engineering 1993, 6,93 .

23. Park, H.-J.; Lee, K.-S.; Cho, S.-H.; Kong, K.-H. Bull. Korean Chem. Soc. 2001, 22, 77.

24. Ji, X.; Von Rosenvinge, E. C.; Johnson, W. W.; Tomarev, S. I.; Piatigorsky, J.; Armstrong, R. N.; Gilliland, G. L. Biochemistry 1995, 34, 5317.

25. Sinning, I.; Kleywegt, G. J.; Cowan, S. W.; Reinemer, P.; Dirr, H. W.; Huber, R.; Gilliland, G. L.; Armstrong, R. N.; Ji, X.; Board, P. G.; Olin, B.; Mannervik, B.; Jones, T. A. J. Mol. Biol. 1993, 232, 192.

26. Wilce, M. C. J.; Board, P. G.; Feil, S. C.; Parker, M. W. EMBO J. 
1995, 14, 2133.

27. Reinemer, P.; Dirr, H. W.; Ladenstein, R.; Huber, R. J. Mol. Biol. 1992, 217,214

28. Johnson, W. W.; Liu, S.; Ji, X.; Gilliland, G. L.; Armstrong, R. N. J. Biol. Chem. 1993, 268, 11508.

29. Ji, X.; Johnson, W. W.; Sesay, M. A.; Dickert, L.; Prasad, S. M.; Ammon, H. L.; Armstrong, R. N.; Gilliland, G. L. Biochemistry 1994, 33, 1043.

30. Widersten, M.; Björnestedt, R.; Mannervik, B. Biochemistry 1994, 33, 11717.

31. Zimniak, P.; Nanduri, B.; Pikula, S.; Bandorowicz-Pikula, J.; Singhal, S. S.; Srivastava, S. K.; Awasthi, S.; Awasthi, Y. C. Eur. J. Biochem. 1994, 224, 893.

32. Bammler, T.; Driessen, H.; Finnstrom, N.; Wolf, C. R. Biochemistry 1995, 34, 9000.

33. Ahn, S.-Y.; Jeon, S.-H.; Park, H.-J.; Kong, K.-H. Bull. Korean Chem. Soc. 2003, 24, 1188.

34. Schramm, V. L.; McCluskey, R.; Emig, F. A.; Litwack, G. J. Biol.
Chem. 1984, 259, 714.

35. Kano, T.; Sakai, M.; Muramatsu, M. Cancer Res. 1987, 47, 5626.

36. Kunkel, T. A. Proc. Natl. Acad. Sci. USA 1985, 82, 488.

37. Parker, M. W.; Bello, M. L.; Federici, G. J. Mol. Biol. 1990, 213 , 221.

38. Habig, W. H.; Jakoby, W. B. Methods Enzymol. 1981, 77, 398.

39. Flohè, L.; Günzler, W. A. Methods. Enzymol. 1984, 105, 114.

40. Ketterer, B.; Tan, K. H.; Meyer, D. J.; Coles, B. Glutahtione STransferase and Carcinog. 1987, 149.

41. Mannervik, B. Adv. Enzymol. Rel. Areas Mol. Biol. 1985, 57, 357.

42. Tsuchida, S.; Sato, K. CRC Crit. Rev. Biochem. Mol. Biol. 1992, $27,337$.

43. Barycki, J. J.; Colman, R. F. Biochemistry 1993, 32, 13002.

44. Pettigrew, N. E.; Moyer-Myers, M.; Colman, R. F. Arch. Biochem. Biophys. 1999, 364, 107.

45. Ji, X.; Von Rosenvinge, E. C.; Johnson, W. W.; Tomarev, S. I.; Piatigorsky, J.; Armstrong, R. N.; Gilliland, G. L. Biochemistry 1995, 34, 5317. 